\title{
Chemical Composition and Physicochemical Analysis of Matured Stems of Opuntia dillenii Grown in Nigeria
}

\author{
Njoku Uche Chinedu, Amadi Benjamin, Amadi Peter* \\ Department of Biochemistry, University of Port Harcourt, Choba, Rivers State, Nigeria
}

Copyright(C2017 by authors, all rights reserved. Authors agree that this article remains permanently open access under the terms of the Creative Commons Attribution License 4.0 International License

\begin{abstract}
This study investigated the chemical composition and physiochemical properties of matured stems of Opuntia dillenii grown in Nigeria in accordance with standard procedures. The proximate analysis revealed moisture content $(11.20 \%)$, crude protein $(11.60 \%)$, carbohydrate content $(64 \%)$ while the ash $(3.33 \%)$, fat $(4.42 \%)$ and crude fibre content $(4.40 \%)$ were low. The phytochemical screening revealed that saponin $(118.08 \pm 0.57 \mu \mathrm{g} / \mathrm{ml})$ was the most concentrated while oxalate and phytate had low concentrations. The physiochemical assessment of the matured stem oil demonstrated high peroxide value, acid value and low iodine value. The fatty acid analysis revealed high concentrations of myristic acid (41.66\%) followed by linoleic acid (13.95\%), heptadecanoic acid (11.32\%) and stearic acid (9.25\%). Unsaturated fatty acids such as oleic acid and linolenic acid were not detected. The study demonstrated that the matured stems of Opuntia dillenii contained nutrients that are nutritionally beneficial to human health and substantial amount of saponins that could be employed in the confectionaries and cosmetic sectors, however the fatty acid analysis demonstrated that these matured stems may not be rich in unsaturated fatty acids while the matured stem oil may be susceptible to auto oxidation and possess a low shelf life.
\end{abstract}

Keywords Opuntia dillenii, Phytochemicals, Fatty Acids, Physicochemical, Proximate

\section{Introduction}

Medicinal plants have experienced enormous patronage and have been exploited in recent times. However, only few events have validated their therapeutic potentials (Sharifi et al., 2014). Therapeutic plants are gaining prominence in developing countries owing to their effectiveness, safety and lesser side effects. In Nigeria, many indigenous plants are used as spices, food or medicine where they exhibit a wide range of biological and pharmacological activities. These plants have exhibited enormous potentials in the development of modern drugs and promotion of effective health care systems in developed and developing countries, and advancement in clinical research depicts the value of herbal medicine in the prevention and treatment of diseases. Plant chemicals derived from proteins, carbohydrates and fats are components of the human body composition and chemistry (Andzouana and Mombouli, 2012), phytochemicals present in these plants, coupled with their elemental composition have been attributed to be responsible for the medicinal quality of these plants. The beneficial role of therapeutic plants in disease prevention and curbing has been attributed to the antioxidant properties of their constituents (Monica et al., 2015). Opuntia (genus) plants are part of the Cactaceae family that is extensively distributed in arid and semi-arid regions all over the world(Butera et al., 2002). Opuntia ficus indica is the largest genus and the commonest species cultivated for commercial processing among the members of this family (Cactaceae) in semi-arid areas of the world (Coria-Cayupan et al., 2011. Moussa Ayoub et al., 2011). Cactus pear cladodes are considered vegetables that originated from tropical America (Amadi et al., 2017). Nopal cactus has been used as herbal remedy for various health problems in different countries, it has been adopted in health, nutrition and cosmetics in various forms such as jam, juice, oil from the seeds and tea (El-Mostafa et al., 2014). The cladodes and fruits are often consumed both fresh and processed in Latin America, whereas only the fresh fruits are more widespread on European and North-American markets (Butera et al., 2002).Though Prickly pear plant is abundant in many locations in Nigeria, there is little or no information regarding its nutritional value in Nigeria, resulting to its underutilization as food and fodder for both human and livestock consumption. Hence, it is important to source for alternative feeds for livestock in order to supplement scarce feeds and improve human nutrition. It was on this 
foregoing that this study was carried out to evaluate the chemical and physicochemical properties of matured stems of Opuntia dinellii grown in Nigeria.

\section{Materials and Methods}

\subsection{Sample Collection and Preparation}

Fresh matured Cactus stems (Opuntia dillenii) were gathered from Umuanuma Nguru in Aboh Mbaise Local Government Area of Imo State. The plant was identified and authenticated at the herbarium unit of the Department of Plant Science and Biotechnology, Imo State University Owerri. The stems were air dried for 22 days and milled into a powder that was stored under dry conditions before analysis.

\subsection{Sample Preparation}

A $100 \mathrm{~g}$ of the ground sample was weighed into a thimble and soaked in $500 \mathrm{ml}$ of a mixture of $\mathrm{n}$-hexane and isopropyl alcohol in a ratio of $3: 2$ according to the stipulations of Hara and Radin(1978). The thimble was stuffed with cotton to prevent the sample particles from pouring away and left for $24 \mathrm{hrs}$. The solution obtained was drained, filtered using filter paper and extracted with a soxhlet extractor. The rotary evaporator was used to concentrate the sample and solvent mixture, at a low pressure with a maximum temperature of $45^{\circ} \mathrm{C}$ to produce the crude extracts and the extracts were stored at $4^{\circ} \mathrm{C}$ before analysis.

\subsection{Chemical Analysis}

\subsubsection{Proximate Analysis}

The proximate analysis was explored according to AOAC (1990) methods. The moisture content was determined by drying in an oven at $100^{\circ} \mathrm{C}$ until a constant weight was obtained. The total ash was determined after weighing and converting the sample to dry ash in a muffle furnance at $550^{\circ} \mathrm{C}$ for incineration. The crude fat content was determined by extraction with hexane via a soxhlet apparatus. The kjeldahl method was employed for crude protein determination and the carbohydrate content was determined by calculating the difference between the sums of all the proximate compositions from $100 \%$.

\subsubsection{Phytochemical Extraction and Analysis}

Extraction of biological active compounds was achieved using the method explored by Nwiloh et al. (2016) with some modifications. One gram of sample was weighed and transferred into a test tube and $15 \mathrm{ml}$ and $10 \mathrm{ml}$ of $50 \% \mathrm{w} / \mathrm{v}$ potassium hydroxide was added. The test tube and its content were heated in a water bath at $60^{\circ} \mathrm{C}$ for $60 \mathrm{mins}$. The reaction product contained in the test tube was transferred into a separatory funnel after the reaction time, and $20 \mathrm{ml}$ of ethanol, $3 \mathrm{ml}$ of hexane, and $10 \mathrm{ml}$ of hot and cold water respectively, were successfully used to wash the tube and they were all transferred to the funnel. This extract was mixed and washed with $10 \mathrm{ml}$ of $10 \% \mathrm{v} / \mathrm{v}$ ethanol aqueous solution three times, and anhydrous sodium sulphate was used to dry the solution and the solvent was evaporated. One thousand micro liter of pyridine was utilized to solubilize the sample of which $200 \mathrm{ml}$ was transferred to a vial for analysis.

Phytochemical analysis of the sample was carried out using an auto system buck 530 chromatographer in gas phase equipped with an on-column automatic injector, flame ionization detector, and with $\mathrm{Hp} 88$ capillary column $(100 \mathrm{~m} \times 0.25 \mathrm{~mm})$. Chromatographic conditions were; injector temperature $220^{\circ} \mathrm{C}$, detector temperature $250^{\circ} \mathrm{C}$, oven temperature to $180^{\circ} \mathrm{C}$, injection volume $=1 \mathrm{ml}$ of the sample, hydrogen was used as a carrier gas ( 24 pound per square inch (PSI)). The concentration of each active component was determined based on the ratio between the area and mass of internal standard and area of the peaks of the phytochemicals identified.

\subsubsection{Fatty Acid Analysis}

Twenty grams of the homogenized sample was combined with $60 \mathrm{~g}$ of anhydrous sodium sulphate in agate mortar to suck up moisture. The homogenate was positioned into an extraction cellulose thimble ( $33 \mathrm{94mm})$, enclosed with a whatman filter paper and slotted into a soxhlet extraction compartment of the soxhlet unit. Extraction was achieved with $200 \mathrm{ml}$ of $\mathrm{n}$-hexane via eicosapentaenoic acid (EPA) $354^{\circ} \mathrm{C}$ method for $8 \mathrm{hrs}$. The collected crude extract was evaporated using a rotary vacuum evaporator at $40^{\circ} \mathrm{C}$, to dryness. Fatty acids methyl esters from matured stems were prepared using the protocol described by (Radwan, 1978) using 1\% sulphuric acid in absolute methanol. The fatty acids methyl esters obtained were separated using Gas Chromatography HP (Hewlett Packard) $6890 \mathrm{GC}$ and the following protocols where observed; Column, Hp-5 (5\% diphenyl, 95\% dimethyl polysiloxane), $30 \mathrm{~m}, 0.32 \mathrm{~mm}$ ID, $0.25 \mu \mathrm{m}$ film thickness, Detector, flame ionization detector, initial temp, $150^{\circ} \mathrm{C}$ for $2 \mathrm{~min}$. Injector temp $220^{\circ} \mathrm{C}$, injection volume $2 \mu \mathrm{l}$, splitless mode, Detector temperature $250^{\circ} \mathrm{C}$. Nitrogen was used as the carrier gas with a flow rate of $1 \mathrm{ml}$ per min.

\subsection{Physicochemical Analysis}

The melting point, moisture, peroxide value, iodine value, acid value and saponification value were determined using the method of AOAC, (2000). The $\mathrm{pH}$ was detected using a $\mathrm{pH}$ meter, the refractive indices analyzed at $25^{\circ} \mathrm{C}$ following the method of Oderinde and Ajayi, (2000) by 
using a Brix refractometer, and the method of Menoyo et al., (2002) was adopted for the determination of TBA-reactive substances (TBARS).

\section{Results and Discussion}

Table 1. Proximate composition of matured stems of Opuntia dillenii

\begin{tabular}{|c|c|c|}
\hline Parameters & Composition (\%) & *Composition $(\mathrm{g} / 100 \mathrm{~g})$ \\
\hline Moisture Content & $11.20 \pm 0.13$ & 0.00 \\
\hline Ash Content & $3.33 \pm 0.18$ & 24.40 \\
\hline Crude Protein & $11.60 \pm 0.21$ & 6.90 \\
\hline Fat & $4.42 \pm 0.19$ & 4.90 \\
\hline Crude Fibre & $4.40 \pm 0.06$ & 36.00 \\
\hline Carbohydrate & $64 \pm 0.14$ & 30.80 \\
\hline
\end{tabular}

Values are means of three determinations \pm standard errors of mean (SEM) *Source: Carreira et al., (2014)

Table 2. Physicochemical properties of Opuntia dillenii matured stem oil

\begin{tabular}{|c|c|}
\hline Properties & Matured stem oil \\
\hline Peroxide Value $(\mathrm{Meq} / \mathrm{KOH} / \mathrm{kg})$ & $15.60 \pm 1.26$ \\
\hline Iodine Value $\left(\mathrm{gI}_{2} / 100 \mathrm{~g}\right)$ & $63.33 \pm 2.40$ \\
\hline Saponification Value $(\mathrm{mgKOH} / \mathrm{g})$ & $158.66 \pm 1.47$ \\
\hline Specific Gravity & $1.19 \pm 0.03$ \\
\hline Melting Point $\left({ }^{\circ} \mathrm{C}\right)$ & $7.03 \pm 0.31$ \\
\hline $\mathrm{pH}$ & $4.56 \pm 0.26$ \\
\hline Acid Value $(\mathrm{mgKOH} / \mathrm{g})$ & $31.00 \pm 2.64$ \\
\hline Refractive $\mathrm{Index}$ & $1.00 \pm 0.03$ \\
\hline Moisture $(\%)$ & $7.00 \pm 1.10$ \\
\hline Thiobarbituric Acid $(\mu \mathrm{g} / \mathrm{kg})$ & $0.22 \pm 0.01$ \\
\hline
\end{tabular}

Values are means of three determinations \pm standard errors of mean (SEM)

Table 3. Phytochemical analysis of matured stem of Opuntia dillenii

\begin{tabular}{|c|c|}
\hline Phytochemicals & Concentration $(\mu \mathrm{g} / \mathrm{ml})$ \\
\hline Anthocyanin & $0.04 \pm 0.02$ \\
\hline Oxalate & $1.07 \pm 0.01$ \\
\hline Tanin & $13.62 \pm 0.05$ \\
\hline Rutin & $12.41 \pm 0.26$ \\
\hline Phenol & $4.66 \pm 0.08$ \\
\hline Lunamarine & $34.43 \pm 0.35$ \\
\hline Saponin & $118.08 \pm 0.57$ \\
\hline Sapogenin & $11.88 \pm 0.09$ \\
\hline Ribalinidine & $3.75 \pm 0.09$ \\
\hline Phytate & $0.18 \pm 0.04$ \\
\hline Kaempferol & $7.90 \pm 0.06$ \\
\hline Catechin & $44.90 \pm 0.38$ \\
\hline
\end{tabular}

Values are means of three determinations \pm standard errors of mean (SEM)
Table 4. Fatty acid composition of matured stems of Opuntia dillenii

\begin{tabular}{|c|c|}
\hline Name & Concentration (\%) \\
\hline $\mathrm{C}_{12}=$ Lauric acid & $7.78 \pm 0.06$ \\
\hline $\mathrm{C}_{14: 0}=$ Myristic acid & $41.24 \pm 0.55$ \\
\hline $\mathrm{C}_{16: 0}=$ Palmitic acid & $5.48 \pm 0.06$ \\
\hline $\mathrm{C}_{17: 0}=$ Heptadecanoic acid & $11.32 \pm 0.06$ \\
\hline $\mathrm{C}_{18: 0}=$ Stearic acid & $9.25 \pm 0.03$ \\
\hline $\mathrm{C}_{20: 0}=$ Arachidic acid & $1.21 \pm 0.06$ \\
\hline $\mathrm{C}_{18: 1}=$ Oleic acid & 0.0000 \\
\hline $\mathrm{C}_{18: 2}=$ Linoleic acid & $13.95 \pm 0.02$ \\
\hline
\end{tabular}

Values are means of three determinations \pm standard errors of mean (SEM)

The moisture content $(11.20 \%)$ of matured stems of Opuntia dillenii (Table 1) was higher than $6.78 \%$ reported by (El-Safy, 2013) in cladode (stem) flours of Opuntia ficus indica, the sample had an ash content of (3.33\%) and this value was lower than $27 \%$ and $21 \%$ reported by El Salfy (2013) and Carreira et al (2014) for Opuntia ficus indica cladodes and Opuntia sulphurea cladodea respectively. These variations may be due to Geographical location, soil, climatic conditions and maturation. The ash constituent of the sample is considerably within the tolerable ash constituent mean values of legumes (2.4 to $5.0 \%$ ) recommended by FAO (1988). Pearson (1976) reported ash content as a guide to assess and grade foods in terms of nutritive quality. In addition, the ash content value of the sample $(3.33 \%)$ was lower compared to the range of (5.43\% to $5.75 \%)$ reported for some edible woody plants (Emmanuel et al., 2011) and (6.14\% and 5.54\%) reported by (Andzouana and Mombouli, 2012) for the leaves of Hippocratea myriantha and Urera trinervis respectively. On the other hand, the $(3.33 \%)$ ash content value of the sample was higher than the range of $0.38-1.9 \%$ for selected vegetables grown in Peshawar (Bangash et al., 2011). The crude protein content $(11.6 \%)$ is higher than $(7.6 \%)$ and $(6.9 \%)$ protein value reported by El-Safy, (2013) and Carreira et al., (2014) but it is within the estimates for various Opuntia species though our findings remains the highest for other Opuntia species which ranges from 4\% to $10 \%$ (Saenz et al., 2006). The lipid content $(4.42 \%)$ of the sample in this study is similar to the lipid content estimate $(4.90 \%)$ reported by Carreira et al., (2014) but higher than (2.20\%) reported by Moreno- Alvarez et al., (2006); El-Safy, (2013); and 1.4\% of dry weight reported by Stintzing and Carle (2005) and Feugang et al., (2006) for other opuntia species. The lipid content estimate of the same was very low in comparison to the $24 \%$ crude fat observed in A. senegalensis (Yameogo et al., 2011). The low fat estimate recorded in matured stems of Opuntia dilleni suggests that these matured stems may beneficial to individuals on weight reducing diets (Emebu and Anyika, 2011). However, the matured stems may not serve as good sources of vegetable oils. Matured stems of Opuntia dillenii had a dietary fiber of $4.4 \%$ of dry sample, and this 
value was lower than $18 \%$ of dry weight, (El -Safy, 2013) and $36 \%$ of dry sample (Carreira et al., 2014) for Opuntia ficus indica and Opuntia sulphurea cladodes. The observed differences could be as a result of climatic conditions and maturation. The carbohydrate content of the studied sample was $64 \%$ of dry weight, which was higher than $30 \%$ and $45 \%$ of dry weight, reported by El-Safy (2013) and Carreira et al., (2014) respectively. However, this value was in accordance with 64-71/100g of dry tissue (Stintzing and Carle 2005, Feugang et al., 2006). Furthermore, the carbohydrate content of the studied sample was significantly higher than the estimates of $15.40 \%$ found in A. hybridus, the $30.38 \%$ in G. Africana and $30.40 \%$ in $C$. pepo (Iheanacho and Udeubani, 2009). The high carbohydrate content found in matured stems of Opuntia dillenii possibly implies that these matured stems can be considered as a potential source of energy (Andzouana and Mombouli, 2012).

The matured stem oil of the studied plant (Table 2) had a peroxide value of $15 \mathrm{meq} / \mathrm{kg}$ and peroxide values greater than $10 \mathrm{meq} / \mathrm{kg}$ is highly susceptible to auto-oxidation as a consequence moisture or presence of trace elements and this was demonstrated by Adebisi and Olagunju, (2011). The peroxide value of oils has been described as the most usual lipid oxidation indicatior (Aremu et al., 2015). Consequently, this outcome suggests that the matured stem oil possesses a lower shelf life. The iodine values in the studied sample was lower than that of Citrullus colocynthis (Igwenyi, 2014), peanut oil and palm oil (Birnin-Yauri and Garba, 2011). The iodine value was below $100 \mathrm{gI}_{2} / 100 \mathrm{~g}$ and this implies that it is a non-drying oil as regards to industrial importance and also, based on the classification of Aremu et al., (2006). The saponification value of the studied sample was similar to those of Telfaria occidentalis oil (Nwabanne, 2012) and Anacardium occidentale oil (Aremu and Akinwumi, 2014) but lower than the values for Jathropha curcas seed oil (Elizabeth et al., 2012) and Sesame seed oil (Mohammed and Hamza, 2008). Low saponification values points to the predominance of long chain fatty acids as suggested by Akintayo and Bayer, (2002). The acid value is a possible indicator of the quality of fatty acids in oil which could in turn resolve the shelf life and stability of particular oil and the $\mathrm{pH}$ and acid values are used to evaluate the amount of free fatty acids present in oils. The acid value found in Opuntia dillenii matured stem oil was higher than the acid value for groundnut oil reported by Ayoola and Adeyeye, (2010), and based on the submissions of Aremu et al. (2006), the matured stem oil of Opuntia dillenii may not be appropriate for cooking. The refractive index of the matured stem oil was below 1.4677-1.4707 (CODEX-STAN, 1999) for refined virgin oils. The lower the moisture content of a food sample, the lesser the vulnerability to microbial spoilage and thus the better the storage capacity. Lukaszewicz et al., (2004) observed that the presence of thiobarbituric acid in an oil indicates that oxidation has already occurred and can be quantified from the amounts present and in addition, these values may be used for sensory testing in order to identify rancidity in foods as suggested by these authors (Fernández et al., 1997; Rhee and Myers, 2003; Campo et al., 2006).

The phytochemical analysis of the matured stems of Opuntia dillenii (Table 3) revealed that catechin and kaempferol are flavonoids with the highest concentrations $(44.90 \mu \mathrm{g} / \mathrm{ml}$ and $12.41 \mu \mathrm{g} / \mathrm{ml})$ respectively while anthocyanin $(0.04 \mu \mathrm{g} / \mathrm{ml})$ and rutin $(0.88 \mu \mathrm{g} / \mathrm{ml})$ exhibited low concentrations. Catechin, a major constituent of green tea has been reported to have anti-cancer, hypotensive, and hypocholesterolemic activities (Yang et al., 2004; Combra et al., 2006; Butt et al., 2013; Masuda et al., 2014). Kaempferol have been attributed to possess antimicrobial potentials as well as antioxidant properties (Singh et al., 1988; Quarenghi et al., 2000; Paolillo et al., 2011). The oxalate and phytate concentrations were low $(1.07 \mu \mathrm{g} / \mathrm{ml}$ and $0.18 \mu \mathrm{g} / \mathrm{ml})$ while tannin was $(13.62 \mu \mathrm{g} / \mathrm{ml})$ and tannins have been attributed to possess possible anti-carcinogenic effect (Butler, 1989), antimicrobial and antioxidant properties (Lin et al., 2001; Buzzini et al., 2008). However, the precipitation of tannins have been observed to obstruct the absorption of protein (Shimada, 2006) thereby underscoring its potentials as an anti-nutrient. Lunamarine and ribalinidine are known alkaloids and their concentrations in the studied sample are $(34.43 \mu \mathrm{g} / \mathrm{ml}$ and 3.75) respectively, alkaloids have exhibited potent therapeutic potentials which range from anti-malarial (Cordell, 1981), analgesic, and antioxidant properties (Stary, 1998) and anti-plasmodial properties (Fozia et al., 2010) among other effects. Saponins demonstrated the highest value $(118.08 \mu \mathrm{g} / \mathrm{ml})$ and its beneficial effects includes anti-inflammatory properties (Odeyemi et al., 2015), anti-cancer (Man et al., 2010) and anti-platelet aggregation activity (Huang et al., 1999) among other benefits. The physicochemical properties of saponins and in addition to its biological activities have led to an increase in its application in cosmetic, food and pharmaceutical industries. Therefore the high saponin content present in matured stems of Opuntia dillenii, qualifies them as useful candidates to be applied in the cosmetic and confectionary sectors.

Fatty acid analysis of the studied plant (Table 4) indicated the presence of eight fatty acids. Myristic acid with $41.66 \%$ composition had the highest concentration. Myristic acid coupled with linoleic acid (13.95\%), heptadecanoic acid (11.32\%) and stearic acid were the major fatty acids found in matured stem of Opuntia dillenii. Lopez-Cervantes et al., (2011) and Carreira et al., 2014 reported that linoleic acid, palmitic acid and oleic acids as the main constituents of Opuntia sulphurea cladodes and Opuntia ficus indica cladodes. However, the absence of oleic acids, linolenic acids and the low concentrations of linoleic acid portray possible low concentrations of these unsaturated fatty acids and this could be a consequence of growing conditions of cladodes, degree of maturation and 
age of cladodes (Coskuner and Tekin, 2003; Ennouri et al., 2005), these researchers observed increase in saturated fatty acid content at the end of fruit maturation of Opuntia ficus indica fruits. Unsaturated fatty acid improves lipid profile while excessive intake of saturated fatty acids results in obesity and elevated cholesterol levels (Brenna et al., 2009). This value indicates further that the matured stems of Opuntia dillenii may not be a rich source of unsaturated fatty acids as a result of the absence of linolenic acid, oleic acids and low concentrations of linoleic acid.

\section{Conclusions}

The matured stems of Opuntia dillenii exhibited useful potentials as a great source of energy as a result of the high carbohydrate content while the phytochemical screening indicates that these matured stems are rich in flavonoids, saponins and alkaloids, this outcome could be of immense benefits due to the enormous therapeutic potentials accrued to these phytochemicals while the physicochemical analysis of the matured stem oil of Opuntia dillenii revealed that the oil may not be suitable for cooking and may be susceptible to auto oxidation and the matured stems demonstrated low concentrations of unsaturated fatty acids.

\section{Conflict of Interest}

The authors declare no conflict of interest regarding this article.

\section{REFERENCES}

[1] AOAC (2000). Official Methods of Analysis. 17th Ed., DC. Association of Analytical Chemists, Washington

[2] Adebisi, G.A. and Olagunju, E. O. (2011). Nutritional potential of the seed of fluted pumpkin (Telfairia occidentalis). J. New Trends Sci. Technol. Applic., 1: 7-18.

[3] Akintayo, E.T. and Bayer, E. (2002). Characterisation and some possible uses of Plukenetia conophora and Adenopus breviflorus seeds and seed oils. Bioresource Technology 85: $95-97$.

[4] AOAC, (1990). Official Methods of Analysis $15^{\text {th }}$ edition, Association of Official Analytical Chemists, Washington, DC, USA, PP: 200-210.

[5] Amadi, B. A., Njoku U. C., Agomuo, E. N., Amadi, P. U., Ezendiokwere, O. E. and Nwauche, K. T. (2017) Assessment of vitamins, protein quality and mineral bioavailability matured stems of Opuntia dillenii grown in Nigeria. Bioengineering and Bioscience, 5(3):47-54.

[6] Andzouana, M. and Mombouli, J. B. (2012). Proximate,
Mineral and Phytochemical Analysis of the Leaves of $\mathrm{H}$. myriantha and Urera trinervis. Pakistan Journal of Biological Sciences, 15: 536-541.

[7] Aremu, M. O. and Akinwumi, O. D. (2014). Extraction, compositional and physicochemical characteristics of cashew (Anacardium occidentale) nuts reject oil. Asian Journal of Applied Science and Engineering, 3, 33 - 40.

[8] Aremu, M. O. Awala, E. Y. Opaluwa, O. D. Odoh, R. and Bamidele, T. O. (2015). Effect of Processing on Nutritional Composition of African Locust Bean (Parkia biglobosa) and Mesquite Bean (Prosopis africana) Seeds, Communications in Applied Sciences 3(1) 22-41.

[9] Aremu, M. O., Olonisakin, A., Bako, D. A. and Madu, P. C. (2006). Compositional studies and physiochemical characteristics of cashew nut (Anacardium occidentale) flour. Pak. J. Nutrition, 5(4): 328 - 333.

[10] Ayoola, P. B. and Adeyeye, A. (2010). Effect of heating on the chemical composition and physico- chemical properties of Arachis hypogea (groundnut) seed flour and oil. Pakistan Journal of Nutrition, 9(8) 751 - 754.

[11] Bangash, J. A., Arif, M., Khan, F., Khan, A. and Hussain, I. (2011) Proximate composition, minerals and vitamin content of selected vegetables grown in Peshawar. J. Chem. Soc. Pak., 33:118-122.

[12] Birnin-Yauri, U.A. and Garba, S. (2011). Comparative Studies on Some Physicochemical Properties of Baobab, Vegetable, Peanut and Palm Oils, Nigerian Journal of Basic and Applied Science, 19(1): 64- 67

[13] Brenna, J.T., Salem, J.N., Sinclair, A. J. and Cunnane, S.C. (2009). $\alpha$-Linolenic acid supplementation and conversion to n-3 long-chain polyunsaturated fatty acids in humans. Prostaglandins Leukot. Essent. Fat. Acids, 80, 85-91.

[14] Butera, D, Tesoriere, L, Di Gaudio, F. (2002) Antioxidant activities of Sicilian Prickly pear (Opuntia ficus-indica) fruit extract and reducing properties of its Betalains; Betanin and Indicaxanthin. Journal of Agricultural and Food Chemistry; 50:6895-6901.

[15] Butler, L.G. (1989). Effects of Condensed Tannins on Animal Nutrition. In: Hemingway, R.W. and Karchesy, J.J. (eds.). Chemistry and significance of condensed tannins. Plenum Press, N.Y.

[16] Butt, M. S., Ahmad, R. S., Sultan, M. T., Nasir-Qayyum, M. M. and Naz, A. (2013) Green Tea and Anti-Cancer Perspectives: Updates from last Decade. Critical Reviews in Food Science and Nutrition 55:792-805.

[17] Buzzini, P., Arapitsas, P., Goretti, M., Branda, E., Turchetti, B. and Pinelli, P. (2008). Antimicrobial and antiviral activity of hydrolysable tannins. Mini Review in Medicinal Chemistry, 8(12):1179-1187.

[18] Campo, M. M., Nute, G.R. Hughes, S.I. Enser, M. Wood J.D. and Richardson, R.I. (2006). Flavour perception of oxidation in beef. Meat Sci. $303-311$.

[19] Carreira, V. P., Padró, J., Koch, N. M., Fontanarrosa, P., Alonso, I. and Soto, I. M. (2014). Nutritional Composition of Opuntia sulphurea G. Don Cladodes. Haseltonia 19:38-45.

[20] CODEX-STAN 210. (1999). Codex Standard for Fats and Oils from Vegetable Sources. 
[21] Combra, S., Santos-Silva, A., Rocha-Pereira, P., Rocha, S. and Castro, E. (2006) Green Tea Consumption improves Plasma lipids profiles in Adults. Nutrition Research 26:604-607.

[22] Cordell, G.A. (1981). Introduction to Alkaloids: A biogenetic Approach. John Willey and Sons, New York.

[23] Coria-Cayupan, Y, S., Ochoa, M.J. and Nazareno, M.A. (2011) Health promoting substances and Anti-oxidant properties of Opuntia Sp. fruits. Changes in Bioactive compound contents during ripening process. Food chemistry; 126:514-519.

[24] Coskuner, Y. and Tekin, A. (2003) Monitoring of seed composition of Prickly pear (Opuntia ficus indica) fruits during maturation period. Journal of the Science of Food and Agriculture, 83 (8): 846-849.

[25] Elizabeth, F. A., Michael, O. D., Tunde, V. O., Mujidat, O. A., Stephen, K. L. and Bamidele, O. S. (2012). Nigerian Jatropha curcas oil seeds: Prospect for biodiesel production in Nigeria. International Journal of Renewable Energy Research, 2(2), $317-325$.

[26] El-mostafa, K., EL-kharassi, Y., Badreddine, A., Andreoletti, P. and Vamecq, J. (2014) Nopal cactus (Opuntia ficus indica) as a source of bioactive compounds for nutrition, health and disease. Molecules, 19:14879-14901.

[27] EL-Safy, S. F. (2013) Evaluation and utilization of cladodes flour in formulating sponge cake, World Applied Sciences Journal 27 (4): 512-523.

[28] Emmanuel, T. V., Njoka, J. T., Catherine, L. W. and Lyaruu, H. V. (2011). Nutritive and anti-nutritive qualities of mostly preferred edible woody plants in selected drylands of Iringa District, Tanzania.

[29] Emebu, P. K. and Anyika, J. U. (2011) Proximate and mineral composition of kale (Brassica oleracea) grown in Delta State, Nigeria. Pak. J. Nutr., 10:190-194.

[30] Ennouri, M., Bourret, E., Mondolot, L. and Attia, H. (2005) Fatty acid composition and rheological behaviour of Prickly pear seed oils. Food Chemistry 93:431-437.

[31] FAO/WHO, (1988). Requirement of vitamin A, iron, folate and vitamin B12: Report of a Joint Expert Consultation. World Health Organization, Rome, Italy, Pages: 107.

[32] Fernández, J., Pérez-Álvarez J.A. and Fernández-López. J.A. (1997). Thiobarbituric acid test for monitoring lipid oxidation in meat. Food Chem. 59: 345-353.

[33] Feugang, J. M., Konarski, P., Zou, D., Stintzing, F. C. and Zou, C. (2006) Nutritional and Medicinal use of Cactus Pear (Opuntia SPP) Cladodes and Fruits. Frontiers in Bioscience 11: 2574-2589.

[34] Fozia, I., Nisar, A., Ijaz, A., Azhar ul, H. and Fanghai, W. (2010). Two new anti-plasmodial flavonoid glycosides from Duranta repens Journal of Enzyme Inhibition and Medicinal Chemistry 25, 6

[35] Hara, A. and Radin, N.S. (1978). Lipids extraction of tissues with a low-toxicity solvent. Analytical Biochemistry 90: $420-426$

[36] Huang, Y. T., Hwang, J. J., Lee, P. P., Ke, F. C., Huang, J. H., Huang, C. J., and Lee, M. T. (1999). Effects of luteolin and quercetin, inhibitors of tyrosine kinase, on cell growth and metastasis-associated properties in A431 cells overexpressing epidermal growth factor receptor. British journal of pharmacology, 128(5), 999-1010.

[37] Igwenyi, I. O. (2014). Comparative study of the physicochemical properties of vegetable oil from Irvigna gabonesis and Citrullus colocynthis dried seeds samples. International Journal of Biochemistry Research \& Review $4(6), 568-573$.

[38] Iheanacho, K. M. E and Udebuani, A. C. (2009) Nutritional composition of some leafy vegetables consumed in Imo State, Nigeria. J. App Sci. Environ. Manage, 13:35-38

[39] Lin, C.C., Hsu, Y.F., Lin, T.C. (2001). Antioxidant and free radical scavenging effects of the tannins of Terminalia catappa L. Anticancer Research., 21(1A):237-243.

[40] Lopez-Cervantes, J., Sanchez-Machado, D. I., Campas-Baypoli, O. N. and Beuno-Solano, C. (2011). Functional properties and proximate composition of Cactus pear cladodes flours. Food Science and Technology 31:654-659.

[41] Lukaszewicz, M. Szopa, J. and Krasowska. A. (2004) Susceptibility of lipids from different flax cultivars to peroxidation and its lowering by added antioxidants. Food Chem. 88: $225-231$.

[42] Man, S., Gao, W., Zhang, Y., Huang, L. and Liu, C. (2010). Chemical study and medical application of saponins as anti-cancer agents. Fitoterapia, 81(7):703-714.

[43] Masuda, S., Maeda-Yamamoto, M., Usui, S. and Fujisawa, T. (2014). Benifuuki green tea containing O-methylated catechin reduces symptoms of Japense cedar pollinosis: A randomized double blind, placebo-controlled trial. Allergology international 63:211-217.

[44] Menoyo, D., C.J. Lo'pez-Bote, J.M. Bautista and A. Obach. (2002). Herring vs. anchovy fish oils in salmon feeding. Aquat. Living Resour. 15:217 - 223.

[45] Mohammed, M. I. and Hamza, Z. U. (2008). Physicochemical properties of oil extracts from Sesamum Indicum L. seeds grown in Jigawa State - Nigeria. Journal of Applied Science \& Environment Management, 12(2), 99 101.

[46] Monica, A., Valdez, S., Veronica, Y., Mejia-Garcia, A. and Tellez- Valencia. (2015). Nutritional content and elemental and phytochemical analyses of Moringa oleifera grown in Mexico. Journal of Chemistry, Article ID 860381, 9 pages.

[47] Moreno-Alvarez, M. J., Carcia-Pantalem, D., Belen-Camacho, D. R., Medina, M., Munoz-Ojeda, N., Herrera, I. and Espinoza, C. (2006) Bromatological evaluation of fruits and cladodes of Prickly pear (Opuntia boldinghii Britton and Rose) Nakari Bulletin, 17:9-12

[48] Moussa-Ayoub, T. E., El-Samahy, S. K., Rohns, S. and Kroh, L.W. (2011) Flavonoids, betacyanins content and anti-oxidant activity of cactus Opuntia macrorhiza fruits. Food Research International, 44: 2169-2174.

[49] Nwabanne, J. T. (2012). Kinetics and thermodynamics study of oil extraction from fluted pumpkin seed. International Journal of Multidisciplinary Sciences and Engineering, 3(6), $11-15$. 
[50] Nwiloh, B. I., Uwakwe, A. A. and Akaninwor, J. O. (2016). Phytochemical screening and GC-FID analysis of ethanolic extract of root bark of Salacia nitida L. Benth. Journal of Medicinal Plant Studies, 4(6):283-287

[51] Oderinde, R.A. and Ajayi, I.A. (2000). Physico-chemical and metal composition of Calophyllum inophyllum seed and seed oil. Pakistan Journal of Industrial Research 43, $357-358$

[52] Odeyemi, S. Afolayan, A. and Bradley. G. (2015) In vitro anti-inflammatory and free radical scavenging activities of crude saponins extracted from Albuca bracteata jacq, Bulb. African Journal of Traditional, Complementary and Alternative Medicine, 12(4) 34-40.

[53] Paolillo, R., Carratelli, C.R. and Rizzo, A. (2011). Effect of resveratrol and quercetin in experimental infection by Salmonella enteric Serovar typhimurium. International Journal of Immunopharmacology, 11:149-156.

[54] Pearson, D. A. (1976) Chemical analysis of foods $\left(7^{\text {th }}\right.$ edition.) Edinburgh: Churchill, Livingstone. P. 422-511.

[55] Quarenghi, M.V., Tereschuk, M.L., Baigori, M.D. and Abdala, L.R. (2000). Antimicrobial activity of flowers from Anthemis cotula. Fitoterapia. 71:710-712.

[56] Radwan, S. S. (1978). Coupling of two-dimensional thin-layer chromatography with gas chromatography for the quantitative analysis of lipid classes and their constituent fatty acids. Journal of Chromatographic Science, 16 (11): 538-542.

[57] Rhee, K. S. and Myers. C.E. (2003). Sensory properties and lipid oxidation in aerobically refrigerated cooked ground goat meat. Meat Sci. 66: 189 - 194.

[58] Saenz, C., Berger, H., Corrales, J., Galletti, L., Garcia, V., Higuera, I., Mondragon, C., Rodriguez-Felix, A., Sepulveda, E. and Varnero, E. (2006). Agro Industrial Uses of Nopal. Agricultural Services Bulletin of the FAO, NO 162 PP: 168.

[59] Sharifi Rad, J., Hoseini Alfatemi, S. M., Sharifi Rad, M. and Iriti, M. (2014). Free radical scavenging and antioxidant activities of different parts of Nitraria schoberi L. Journal of Biologically Active Products from Nature, 4(1), 44-51.

[60] Shimada, T. (2006). Salivary proteins as a defense against dietary tannins, J Chem. Ecol. 32(6):1149-63.

[61] Singh, U.P., Pandey, V.B., Singh, K.N. and Singh, R.O.N. (1988). Structural and biogenic relationships of isoflavonoids. Canadian Journal of Botany, 166:1901-1910.

[62] Stary, F. (1998). The Natural Guide to Medicinal Herbs and plants. Tiger Books International, London, 12-16.

[63] Stintzing, F. C. and Carle, R. (2005). Cactus Stems (Opuntia SPP): A Review on Their Chemistry, Technology and Uses. Mol. Nutr. Food Res, 49: 175-194.

[64] Yameogo, C. W., Bengaly, M. D., Savadogo, A. Nikiema, P. A. and Traore, S. A. (2011) Determination of chemical composition and nutritional values of Moringa oleifera leaves. Pak. J. Nutr., 10:264-268.

[65] Yang, Y. C., Lu, F. H., Wu, J. S., Wu, C. H. and Chang, C. J. (2004) The Protective Effect of Habitual Tea Consumption on Hypertension. Arch Intern Med 164:1534-1540. 